\title{
PENGARUH INTELLECTUAL CAPITAL (HUMAN CAPITAL, STRUCTURAL CAPITAL DAN CUSTOMER CAPITAL) TERHADAP KINERJA PERUSAHAAN MANUFAKTUR YANG TERDAFTAR DI BURSA EFEK INDONESIA
}

\author{
Afni Eliana Saragih, S.E.M.Si
}

\begin{abstract}
Abstrak
Menghadapi persaingan yang semakin tinggi, perusahaan tidak dapat hanya bertahan mengandalkan modal fisik. Perusahaan dituntut untuk mengusahakan dan mengoptimalkan modal intelektual (intellectual capital). Penelitian ini bertujuan untuk menguji pengaruh intellectual capital yang terdiri dari human capital, structural capital dan customer capital terhadap kinerja perusahaan. Objek penelitian ini adalah perusahaan manufaktur yang terdaftar di Bursa Efek Indonesia. Hasil penelitian ini menunjukkan bahwa secara simultan intellectual capital berpengaruh signifikan positif terhadap kinerja perusahaan. Secara parsial, human capital (VAHU) berpengaruh signifikan negatif terhadap kinerja perusahaan. Hal ini disebabkan perusahaan manufaktur masih menggunakan banyak asset tetap dalam proses operasionalnya. Sedangkan variabel structural capital (STVA) dan customer capital (VACA) berpengaruh signifikan positif terhadap kinerja perusahaan.
\end{abstract}

Kata kunci: intellectual capital, human capital, structural capital, customer capital, ROA

\section{PENDAHULUAN}

Ada sebuah pertanyaan menarik bagi perusahaan yaitu, "mengapa kinerja perusahaan didalam suatu industri yang sama dapat bervariasi?". Sebuah perusahaan dapat menghasilkan laba yang tinggi diantara perusahaan lainnya mengalami kerugian. Kondisi yang lain, perusahaan sama-sama memperoleh keuntungan, namun ada yang memperoleh laba yang lebih unggul dibandingkan perusahaan lain. Fenomena tersebut merupakan suatu kajian yang terus menjadi perhatian perusahaan, karena kinerja tersebut merupakan indikator penentu keberlangsungan perusahaan.

Usaha-usaha untuk menganalisis faktor-faktor yang mempengaruhi kinerja perusahaan yang terdaftar di pasar modal di berbagai negara terus dilakukan seperti penelitian yang dilakukan oleh Ballas et al. (2012), Chi dan Wang (2010), Chau dan Leung (2006). Hal ini terus dilakukan mengingat kinerja perusahaan tidak dapat dilepaskan dari perubahan lingkungan bisnis. Persaingan global terus berubah dan kebutuhan konsumen juga berubah. Untuk menjawab pertanyaan di atas, mengapa perusahaan dapat menghasilkan jumlah laba yang bervariasi salah satunya 
adalah karena perusahaan-perusahaan tersebut berbeda dalam hal intellectual capital.

Intellectual capital diklasifikasikan menjadi 3 (tiga) bagian yaitu human capital, structural capital dan customer capital (Green dan Ryan, 2005). Human capital merupakan dimensi intellectual capital yang berkaitan dengan pengetahuan dan pengalaman manusia, yang akan mempengaruhi nilai perusahaan dengan cara mempengaruhi elemen lain dalam perusahaan. Structural capital, merupakan setiap hal yang dihasilkan oleh karyawan, database, software, panduan, struktur organisasi dan lain sebagainya. Umumnya berkaitan dengan pengetahuan dalam infrastruktur yang menjelaskan variabel struktur organisasi, budaya dan teknologi (Ahmad, 2011). Customer capital , merupakan asset yang tampak dari reputasi perusahaan dan loyalitas konsumen. Customer capital merupakan hubungan harmonis yang dimiliki oleh perusahaan dengan para mitranya, baik yang berasal dari para pemasok yang dapat diandalkan dan berkualitas.

Beberapa tahun belakangan, telah terjadi pergerakan perekonomian ke arah ekonomi berbasis ilmu pengetahuan. Dalam ekonomi berbasis ilmu pengetahuan manager bergerak menemukan berbagai cara untuk menghasilkan kombinasi produk, menguasai pangsa pasar dan mengeliminasi hambatan-hambatan memasuki pasar. Hal ini dilakukan sebagai strategi bertahan dan memperoleh keunggulan dalam persaingan pasar yang semakin ketat. Dalam mencapai hal tersebut pokok yang disoroti adalah asset tidak berwujud dan intellectual capital. Pada pertengahan abad ke 20 ini, menurut Daneshi (2013), pertumbuhan ekonomi secara esensial berubah dan pada akhirnya ilmu pengetahuan menggantikan sumber daya keuangan dan modal berbentuk fisik. Dengan kata lain, ekonomi berbasis ilmu pengetahuan menggantikan ekonomi berbasis industri dan ilmu pengetahuan telah menjadi faktor penentu kreatifitas untuk menghasilkan nilai bagi perusahaan.

Tabel 1

Market Value and Assets (in billions of dollars)

\begin{tabular}{|l|c|c|c|c|c|}
\hline \multicolumn{1}{|c|}{ Company } & $\begin{array}{c}\text { Market } \\
\text { Value }\end{array}$ & Revenue & Profits & Net assets & Hidden Value \\
\hline General Electric & 169 & 79 & 7.3 & 31 & $138(82 \%)$ \\
\hline Coca-cola & 148 & 19 & 3.5 & 6 & $142(96 \%)$ \\
\hline Exxon & 125 & 119 & 7.5 & 43 & $82(66 \%)$ \\
\hline Microsoft & 119 & 9 & 2.2 & 7 & $112(94 \%)$ \\
\hline Intel & 113 & 21 & 5.2 & 17 & $96(85 \%)$ \\
\hline
\end{tabular}


Suwarjono (2003) mengungkapkan bahwa "the market value of these companies is many times their net asset value, that is the value of their physical. The difference between the two values is the company's "hidden value" which can be expressed as a percentage of the market value". Artinya sekalipun nilai asset berwujudnya hanya sedikit, tetapi pasar menilai perusahaan bernilai tinggi yaitu adanya nilai yang tidak nampak (hidden value) perusahaan. Hidden value tersebut sering disebut intellectual capital. Seperti tampak pada Tabel 1, beberapa perusahaan terkemuka seperti Microsoft yang memilki aktiva berwujud yang tidak signifikan dalam laporan keuangan namun penghargaan pasar atas perusahaan tersebut sangat tinggi. Dengan menggunakan pengetahuan dan teknologi akan diperoleh cara menggunakan sumber daya lainnya secara efisien dan ekonomis yang pada akhirnya akan memberikan kenggulan bersaing bagi perusahaan (Suwarjono, 2003).

Ahmad dan Mushraf (2011) menguji hubungan antara intellectual capital dengan kinerja bisnis pada perusahaan industri di Irak. Hasil penelitannya menemukan bahwa terdapat hubungan yang positif dan signifikan antara intellectual capital dengan kinerja perusahaan. Hasil penelitian ini didukung oleh Sofian et al., (2006), Ongkorahardjo et al., (2008), Chen (2008), Pardede (2010), Nejadirani et al., (2012), Soetedjo dan Mursida (2014) Survilaite (2015) dan Akanbi (2016).

Implementasi intellectual capital merupakan suatu hal yang baru, tidak hanya di Indonesia tetapi juga di lingkungan bisnis global. Di Indonesia, intellectual capital masih belum dikenal secara luas. Dalam banyak kasus, sampai saat ini perusahaan-perusahaan di Indonesia masih menggunakan basis ekonomi konvensional dalam membangun bisnisnya sehingga produk yang dihasilkan masih miskin kandungan teknologi. Selama ini intellectual capital tidak dipertimbangkan sebagai asset, namun pada dasarnya terdapat biaya-biaya untuk menghasilkan intellectual capital tersebut. Seiring dengan perkembangan ilmu pengetahuan, dan memang intellectual capital membawa dampak positif bagi perusahaan maka intellectual capital semakin disoroti. Namun hasil penelitian juga tidak selalu konsisten. Bersumber dari fenomena yang terjadi dan hasil penelitian sebelumnya, maka penelitian ini akan menguji pengaruh intellectual capital terhadap kinerja Perusahaan. 


\section{TELAAH PUSTAKA}

\subsection{Resource Based Theory}

Asumsi mendasar dari pandangan resource based theory adalah bahwa organisasi dapat berhasil jika mencapai dan mempertahankan keunggulan bersaing. Keunggulan bersaing dapat dicapai dengan mengimplementasikan strategi penciptaan nilai dimana pesaing tidak dapat meniru dan tidak ada produk pengganti (Hitt et al., 2007). Kapabilitas yang bernilai (valueable), langka (rare), sulit ditiru (costly to imitate) dan tidak dapat disubstitusi (nonsubstitutable) merupakan kompetensi utama perusahaan (core competencies). Jika salah satu syarat dari ke empat unsur tersebut tidak terpenuhi maka keunggulan bersaing tidak akan bertahan lama.

Dengan demikian untuk memperoleh keunggulan bersaing yang bertahan lama kompetensi perusahaan tersebut tidak dapat ditiru dan tidak ada barang penggantinya dari pandangan konsumen. Seberapa lama keunggulan bersaing dapat dipertahankan tergantung dari seberapa cepat pesaing dapat meniru barang atau jasa tersebut atau prosesnya. Keunggulan bersaing yang bertahan lama hanya dapat diperoleh ketika keempat unsur tersebut dapat dipenuhi secara bersamaan. Intellectual capital yang terdiri dari human capital, structural capital dan customer capital dapat menjadi dasar untuk menghasilkan keunggulan bersaing (Marr, 2004 dalam Daneshi, 2013).

\subsection{Intellectual Capital}

Intellectual capital (termasuk juga sebagai asset tidak berwujud) didefenisikan sebagai asset yang tidak tampak secara fisik tetapi memberikan manfaat bagi perusahaan di masa mendatang (Canibano, 2000 dalam Ahmad 2011). Menurut Gioacasi (2007) intellectual capital dipertimbangkan sebagai sumber daya perusahaan dalam rangka membentuk kesehatan perusahaan dan memberi nilai bagi perusahaan.

Dalam proses klasifikasi komponen intellectual capital, umumnya diklasifikasikan menjadi 3 (tiga) bagian yaitu human capital, structural capital dan customer capital (Edvinsson dan Malone, 1997; Green dan Ryan, 2005; Sveiby, 1997 dalam Gioacasi, 2007) . Menurut (Ahmad, 2011) intellectual capital merupakan jumlah agregat nilai asset tidak berwujud yang terdiri dari: 


\section{a. Human capital}

Human capital, merupakan keahlian, pengetahuan dan kemampuan. Human capital merupakan dimensi intellectual capital yang berkaitan dengan pengetahuan dan pengalaman manusia, yang akan mempengaruhi nilai perusahaan dengan cara mempengaruhi elemen lain dalam perusahaan. Pengetahuan dan kapabilitas karyawan merupakan sumber yang sangat penting dalam inovasi perusahaan (Wang dan Chang, 2005)

Dapat dikatakan bahwa human capital sangat dekat mempengaruhi inovasi perusahaan. Karyawan dibutuhkan untuk menjalankan proses produksi perusahaan. Dengan menyediakan kualitas pelayanan yang memadai ketika mengimplementasikan proses produksi, kapabilitas karyawan akan mempengaruhi efisiensi dan kepuasan konsumen . Daneshi (2013) fokus meneliti hubungan konsumen dengan kemampuan karyawan. Penelitiannya menemukan bahwa karyawan seharusnya memiliki pengetahuan dan keahlian yang sesuai untuk memenuhi kebutuhan konsumen. Menurut Wang dan Chang (2005) dalam Daneshi (2013), human capital mempengaruhi kinerja perusahaan melalui proses produksi dan inovasi.

\section{b. Structural capital}

Structural capital, merupakan setiap hal yang dihasilkan oleh karyawan, database, software, panduan, struktur organisasi dan lain sebagainya. Menurut Bontis (2002) dalam Daneshi (2013) structural capital merupakan pusat pengetahuan dalam perusahaan termasuk teknologi. Umumnya berkaitan dengan pengetahuan dalam infrastruktur yang menjelaskan variabel struktur organisasi, budaya dan teknologi (Ahmad, 2011).

Di sisi lain, menurut Daneshi (2013) Structural capital merupakan hardware, software, database, struktur organisasi, hak paten, nama baik perusahaan dan hal lainnya yang digunakan tenaga kerja perusahaan untuk mendukung proses dan aktifitas bisnis perusahaan. Hasil structural capital lebih ditekankan pada pengetahuan yang melekat pada tenaga kerja perusahaan dengan menjalankan rutinitas organisasi (Bontis, 2001 dalam Ahmad, 2011). Aspek budaya dan teknologi yang digabungkan dengan structural capital memiliki keterikatan lebih terhadap pengetahuan berbasis infrastruktur.

Structural capital termasuk faktor teknologi dan kemampuan teknikal (Bontis et al., 2001 dalam Ahmad, 2011) menyatakan bahwa hubungan antara structural capital dan human capital dapat dialokasikan ke dalam 
hubungan social. Karakteristik social menghubungkan setiap individu dalam sebuah perusahaan. Karakteristik social merupakan salah satu hasil keluaran (output) structural capital seperti yang disebutkan oleh (Bontis et al., 2001 dalam Ahmad, 2011). Hasil keluaran tersebut merupakan perngetahuan atau hubungan yang tidak tampak namun memiliki manfaat penting bagi perusahaan (tacit knowledge). Di antara komponen intellectual capital, structural capital merupakan komponen yang paling sulit didefinisikan karena berkaitan dengan sumber daya lainnya.

\section{c. Customer capital}

Customer capital, merupakan asset yang tampak dari reputasi perusahaan dan loyalitas konsumen. Customer capital didefenisikan sebagai sumber daya yang berkaitan dengan konsumen. Customer capital, merupakan hubungan yang dibangun dengan konsumen dan bagian lain yang signifikan dari structural capital. Customer capital merupakan hubungan harmonis yang dimiliki oleh perusahaan dengan para mitranya, baik yang berasal dari para pemasok yang dapat diandalkan dan berkualitas. Customer capital juga timbul dari konsumen yang loyal dan merasa puas akan pelayanan yang telah diberikan yang akan membuat mereka tetap kembali kepada perusahaan yang bersangkutan.

\subsection{Kinerja Perusahaan (Business Perpormance)}

Kinerja perusahaan didefenisikan sebagai hasil yang dapat diukur dari tingkat pencapaian tujuan perusahaan atau hasil kerja dan kemampuan manajemen perusahaan mengimplementasikan strategi yang ditetapkan (Anthony, 1998 dalam Ahmad, 2011). Evaluasi kinerja perusahaan merupakan langkah yang menolong manajemen menilai keputusankeputusannya terkait kinerja perusahaan dengan memilih indikator, pengumpulan dan analisis data, mengakses informasi terkait kriteria kinerja, pelaporan dan komunikasi serta secara berkala meninjau dan mengembangkan setiap prosesnya.

Dalam sistem pengendalian formal ukuran kinerja dapat dibedakan antara ukuran financial dan non financial (Fisher, 1998 dalam Divianto, 2010). Ukuran financial menunjukkan berbagai tindakan yang dilakukan perusahaan di luar lingkup keuangan. Peningkatan nilai perusahaan merupakan hasil dari berbagai kinerja operasional baik keuangan maupun nonkeuangan. Kinerja non keuangan yang dimaksud dapat berupa meningkatnya kepercayaan konsumen terhadap produk yang dihasilkan perusahaan, meningkatnya produktivitas dan komitmen pegawai (Mulyadi 
dan Setyawan, 2001 dalam Divianto, 2010). Dengan demikian, jika perusahaan ingin memperoleh kinerja keuangan yang diharapkan, maka seharusnya perusahaan tersebut memotivasi pegawainya dalam lingkup non keuangan. Hal ini disebabkan suatu penelitian yang dilakukan oleh Ferrier dan Mckenzie (2004) dalam Divianto (2010) menunjukkan bahwa penggerak utama kinerja keuangan jangka panjang adalah kinerja non keuangan. Penelitiannya mengemukakan kesuksesan 90 (Sembilan puluh) perusahaan di Australia dipengaruhi oleh faktor-faktor berikut:
a. Mencoba menemukan potensi para pegawainya.
b. Berusaha meningkatkan profil perusahaannya.
c. Memasuki hubungan strategis dengan pihak ekstern perusahaan dengan menggunakan reputasi dan jaringan bisnis.
d. Melakukan investasi dalam bidang riset dan pengembangan.

\subsection{Intellectual Capital dan Kinerja Perusahaan}

Intellectual capital memiliki peranan yang sangat penting yaitu sebagai sumberdaya untuk menghasilkan keunggulan bersaing bagi perusahaan. Lebih jelasnya dinyatakan bahwa intellectual capital merupakan sumber daya strategis perusahaan yang utama untuk menghasilkan keuntungan. Menurut Marr (2004) dalam Daneshi (2013) intellectual capital memberikan kontribusi dalam hal peningkatan posisi bersaing perusahaan. Lebih lanjut, intellectual capital memampukan perusahaan menghasilkan nilai tambah yang mengarah pada keunggulan bersaing. Nilai tambah tersebut berasal dari peningkatan efektifitas dan efisiensi dari kegiatan rutin perusahaan. Dengan demikian intellectual capital merupakan salah satu faktor kunci sukses perusahaan. Untuk memperoleh keunggulan bersaing, sangat penting bagi perusahaan untuk menggunakan pengetahuan secara efisien dan peningkatan potensi inovasi.

Lebih lanjut, pelaporan asset tidak berwujud ini kepada pemangku kepentingan (stakeholder) seperti investor, kreditor maupun konsumen akan menjadi faktor penentu kesuksesan perusahaan. Mengingat hal ini, adalah sangat penting bagi perusahaan untuk mengelola Intellectual capital yang dimilikinya demi pencapaian tujuan perusahaan. Gambar 1.1 berikut ini menjelaskan bagaimana intellectual capital mempengaruhi kinerja perusahaan. 
Gambar 1.1 Pengaruh Intellectual capital dengan Kinerja Perusahaan

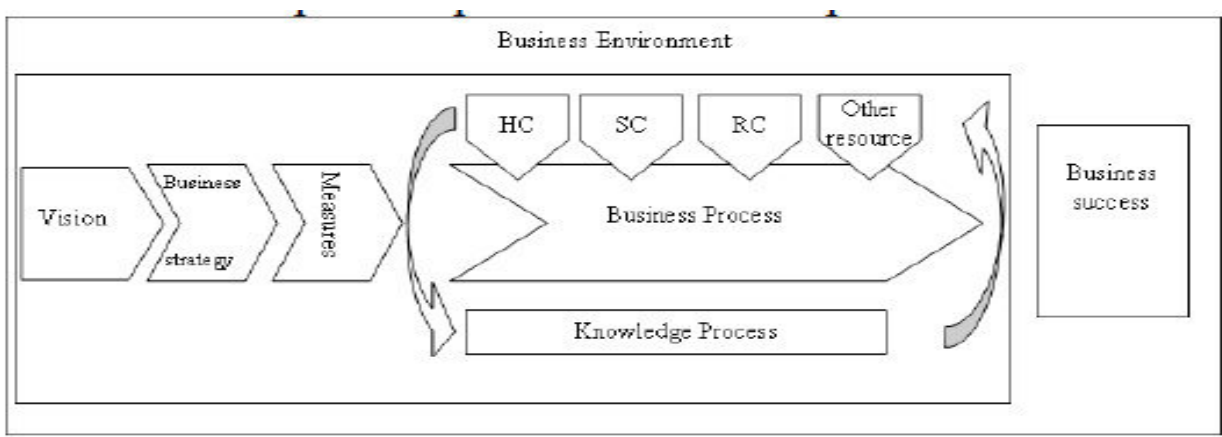

Singkatnya, intellectual capital dikenal sebagai sumber daya yang sangat berpengaruh bagi perusahaan dan menghasilkan keunggulan bersaing. Dengan kata lain, komponen intellectual capital merupakan basis bagi perusahaan untuk mempertahankan keunggulannya (Kaplan dan Norton, 1996 dalam Ahmad, 2011).

\subsection{Pengembangan Hipotesis}

\subsubsection{Pengaruh Human capital Terhadap Kinerja Perusahaan}

Penelitian terkait dilakukan oleh Wang dan Chang (2005) dalam Ahmad (2011) menunjukan bahwa elemen intellectual capital berpengaruh langsung dengan kinerja perusahaan. Penelitian tersebut juga menemukan bahwa terdapat hubungan positif antara intellectual capital dengan kinerja perusahaan dan di dalamnya juga terkandung hubungan sebab akibat di antara keempat elemen intellectual capital. Inovasi akan mempengaruhi proses produksi, yang pada akhirnya mempengaruhi customer capital. Selanjutnya, Customer capital memberi dampak terhadap kinerja.

Penelitian sebelumnya telah menemukan bahwa human capital merupakan kunci utama pencapaian kinerja perusahaan (Gimeno et al., 1997 dalam Juma, 2006). Menurut Becker (1964) dalam Juma (2006) pendidikan dan pengalaman kerja merupakan karakteristik dasar pembentukan konsep human capital . Gabungan pendidikan dengan pengalaman tim manajemen puncak akan menciptakan sumber daya yang kuat dan menciptakan keunggulan bersaing (Dimov dan Shepherd, 2005).

Berdasarkan resources based view dalam kaitannya dengan human capital, pendidikan dan pengalaman tim manajemen puncak adalah sangat bernilai, lagka, tidak dapat ditiru dan merupakan sumber daya yang tidak 
dapat digantikan (Barney, 1991 dalam Juma, 2006). Didukung oleh knowledge based view, pengetahuan merupakan sumber daya yang sangat strategis dan signifikan (Spender, 1996 dalam Juma, 2006). Namun demikian pengetahuan dan pengalaman tersebut tersebar pada berbagai jenis industri dan perusahaan, sehingga kinerja setiap perusahaan akan bervariasi.

Spender (1996) dalam Juma (2006) berargumen bahwa pengetahuan yang paling strategis dan signifikan merupakan kombinasi pengetahuan yang tersimpan dalam individu namun dapat diakses dan terus berkelanjutan dalam aktivitasnya. Intinya, human capital merupakan pengetahuan dan skill yang dibawa individu ke dalam perusahaan (Dimov dan Shepherd, 2005). Dengan demikian human capital yang dimiliki tim manajemen puncak, yang terkandung dalam pendidikan dan pengalamannya akan menciptakan kinerja positif perusahaan. Dengan demikian hipotesis penelitian ini dituliskan sebagai berikut:

H1: Human capital berpengaruh positif signifikan terhadap kinerja perusahaan

\subsubsection{Pengaruh Structural capital Terhadap Kinerja Perusahaan}

Structural capital didefenisikan sebagai hak cipta, hak paten, merek dagang, hak design dan bentuk lain yang secara legal melindungi hak kepenmilikan atas asset intelektual yang spesifik. Perusahaan dapat memperolehnya melalui investasi secara internal dalam penelitian dan pengembangan maupun kerja sama dengan pihak eksternal seperti pemasok, konsumen dan pihak lain yang relevan dengan perusahaan (Hayton, 2005). Kemampuan perusahaan untuk menggali suatu hal yang bernilai baru, informasi eksternal, mengasimilasi dan mengaplikasikannya untuk menciptakan produk baru merupakan fungsi dari kapasitas penyerapan individu dan berkaitan dengan pengetahuan (Cohen dan Lvinthal, 1990 dalam Juma, 2006). Menurut mereka, perusahaan yang tidak memiliki usaha untuk melakukan penelitian dan pengembangan, perusahaan tersebut akan sulit untuk dikenal pasar, sulit berintegrasi dengan kebutuhan konsumen. Dengan demikian diharapkan perusahaan akan bersaing untuk melakukan penelitian dan pengembangan yang tampak dari hak paten yang dimiliki, merek dagang dan asset intelektual lainnya.

Structural capital merupakan sebuah indikator keunggulan teknologi yang dimiliki perusahaan (Lehman, 1996 dalam Juma, 2006). Lebih lagi, penguasaan akan teknologi dapat memberikan hambatan bagi 
perusahaan pendatang baru dan membatasi kemungkinan pesaing untuk meniru produk yang dihasilkan. Structural capital yang terkandung dalam hak paten, merek dagang, teknologi, secara positif akan mempengaruhi kinerja perusahaan. Dengan demikian, hipotesis ketiga dirumuskan sebagai berikut:

H2: Structural capital berpengaruh positif signifikan terhadap kinerja perusahaan.

\subsubsection{Pengaruh Customer capital Terhadap Kinerja Perusahaan}

Customer capital didefenisikan sebagai kumpulan manfaat potensial yang diperoleh dari hubungan baik dengan perusahaan eksternal (Chung, Singh dan Lee, 2000 dalam Juma, 2006). Customer capital juga dapat didefenisikan sebagai asset tidak berwujud yang dapat membantu perusahaan dalam hal mendapatkan keunggulan bersaing (Alder dan Kwon, 2002 dalam Juma, 2006). Para peneliti juga menyimpulkan bahwa kolaborasi antar perusahaan dapat menjadi sumber keunggulan bersaing, karena hubungan tersebut memungkinkan perusahaan mengakses sumber daya lebih mudah dan memperoleh manfaat dari hubungan tersebut (Srivastava, 2001 dalam Juma, 2006). Umumnya kolaborasi antar perusahaan memungkinkan terjadinya pertukaran pengetahuan, termasuk pertukaran pengalaman dan skill yang dapat menghasilkan proses belajar bersama (Dyer dan Singh, 1998 dalam Juma, 2006). Kolaborasi antar perusahaan memungkinkan perusahaan memperoleh akses yang lebih mudah untuk mendapatkan ide, hak paten, proses dan bentuk asset intelektual lainnya. Praktik ini juga akan dapat mengurangi biaya, misalnya biaya penelitian dan pengembangan dan meningkatkan kemampuan perusahaan untuk melakukan inovasi.

Menurut Pfeffer dan Salancik (1978) dalam Juma (2006), perusahaan akan melakukan kerja sama atau kolaborasi dalam rangka meningkatkan kemampuan bersaing dan mencapai tujuan perusahaan. Kerja sama tersebut termasuk strategi aliansi, joint venture, perjanjian kontrak, merger atau hubungan kerja sama dengan konsumen maupun pemasok. Perjanjian kerja sama dapat mengurangi kemungkinan tindakan oppurtunis dari perusahaan patner dan memungkinkan perusahaan untuk memiliki perencanaan yang lebih akurat dalam rangka mengurangi biaya. Dengan demikian investasi dalam customer capital membawa manfaat ekonomi tidak hanya mengurangi biaya namun juga mengembangkan pengetahuan. 
H3: Customer capital berpengaruh positif signifikan terhadap kinerja perusahaan.

\section{METODE PENELITIAN}

\subsection{Populasi dan Sampel}

Populasi dalam penelitian ini adalah perusahaan manufaktur yang terdaftar di Bursa Efek Indonesia tahun 2014-2015. Perusahaan manufaktur dipilih karena sesuai dengan topik penelitian, di mana perusahaan manufaktur dianggap mewakili perusahaan yang menggunakan human capital dalam memproduksi barang, structural capital dalam menjalankan operasinya dan berhubungan dengan konsumen dalam pemasaran produk. Sampel merupakan bagian dari populasi yang diambil melalui cara-cara tertentu, jelas dan lengkap (Sekaran, 2006). Tehnik pengambilan sampel dalam penelitian ini adalah menggunakan tehnik purposive sampling dengan memenuhi kriteria berikut:

a. Perusahaan manufaktur yang terdaftar di Bursa Efek Indonesia selama sampel penelitian dan telah diaudit.

b. Perhitungan yang positif atas VA, HC, SC dan CE

c. Semua data yang diperlukan tersedia, yaitu total penjualan, beban penjualan dan biaya-biaya lain (selain beban karyawan), dana yang tersedia (ekuitas, laba bersih), beban karyawan, dan total asset.

\subsection{Jenis dan Sumber Data}

Jenis data dalam penelitian ini adalah data sekunder, yaitu data yang telah dikumpulkan oleh lembaga pengumpul data dan dipublikasikan kepada masyarakat. Data sekunder yang dimaksud adalah laporan keuangan perusahaan keuangan yang terdaftar di Bursa Efek Indonesia pada tahun 2014-2015. Laporan keuangan tersebut diakses dari situs www.idx.go.id kemudian dianalisis untuk memperoleh data yang dibutuhkan.

\subsection{Variabel Penelitian dan Pengukuran}

\section{Variabel Independen}

Variabel independen dalam penelitian ini adalah human capital, structural capital dan customer capital yang merupakan komponen yang terdapat pada intellectual capital.

1.1. Human capital

Human capital diukur menggunakan konsep output sebagai proksi dari sumber daya berbasis pengetahuan (Cheng et al., 2010). Selain itu 
efisiensi manajer dan karyawan yang bersifat kuantitatif juga menunjukkan human capital sebagai produktivitas dan nilai tambah karyawan. Pengukuran human capital dalam penelitian ini mengadopsi pengukuran yang digunakan Cheng et al., 2010 yang terdiri dari produktivitas karyawan, produktivitas per gaji rata-rata direktur, laba operasi per karyawan, laba operasi per gaji rata-rata direktur, nilai tambah per karyawan dan nilai tambah per gaji rata-rata direktur.

\subsection{Customer capital}

Customer capital, merupakan asset yang tampak dari reputasi perusahaan dan loyalitas konsumen. Mengacu pada penelitian Wang dan Chang (2005) dalam Kusumowati (2013), customer capital diukur dari empat indikator utama, yaitu tingkat pertumbuhan pendapatan, rasio biaya penjualan dan administrasi umum terhadap total biaya dan rasio biaya penjualan dan administrasi umum perusahaan terhadap pendapatan serta beban iklan.

\subsection{Structural capital}

Structural capital, merupakan setiap hal yang dihasilkan oleh karyawan, database, software, panduan, struktur organisasi dan lain sebagainya. Structural diukur dengan mengurangkan value added dengan human capital (Public, 2000 dalam Soetedjo dan Mursida (2014).

\section{Variabel dependen}

Variabel dependen dalam penelitian ini adalah kinerja perusahaan. Kinerja perusahaan didefenisikan sebagai hasil yang dapat diukur dari tingkat pencapaian tujuan perusahaan atau hasil kerja dan kemampuan manajemen perusahaan mengimplementasikan strategi yang ditetapkan. Return on Asset (ROA) digunakan sebagai indikator untuk mengukur kinerja perusahaan, mengacu pada penelitian Soetedjo dan Mursida (2014). ROA dapat dihitung dengan menggunakan formula berikut ini. $\mathrm{ROA}=\frac{\text { Laba Bersih }}{\text { Total Asset }}$

\section{Pengukuran}

Sejalan dengan tujuan yang ingin dicapai dalam penelitian ini, yakni menguji pengaruh intellectual capital yang terdiri dari human capital, structural capital dan customer capital terhadap kinerja perusahaan. Maka penelitian ini akan menggunakan regresi linier berganda untuk menguji pengaruh variabel secara simultan/bersama-sama dan regresi sederhana untuk menguji pengaruh masing-masing bagian intellectual capital. 
Penelitian ini akan meggunakan metode value added intellectual coefficient (VAIC) yang dikembangkan oleh Pulic (1997) dalam Survilaite (2015) yang didesain untuk menyajikan informasi tentang value creation efficiency dari aset berwujud (tangible asset) dan aset tidak berwujud (intangible assets) yang dimiliki perusahaan. VAIC merupakan instrumen untuk mengukur kinerja intellectual capital perusahaan. Model ini dimulai dengan kemampuan perusahaan untuk menciptakan value added (VA). Value added adalah indikator paling objektif untuk menilai keberhasilan bisnis dan menunjukkan kemampuan perusahaan dalam penciptaan nilai (value creation). VA dihitung sebagai selisih antara output dan input.

Berikut ini adalah langkah menghitung VAIC:

1. Menghitung Value Added (VA)

VA dihitung sebagai selisih antara output dan input.

$\mathbf{V A}=\mathbf{O U T}-\mathbf{I N}$

Keterangan:

OUT $=$ Output: total penjualan dan pendapatan lain .

IN = Input: beban penjualan dan biaya-biaya lain (selain beban karyawan).

2. Menghitung Value Added Capital Employed (VACA)

VACA adalah indikator untuk VA yang diciptakan oleh satu unit dari physical capital. Rasio ini menunjukkan kontribusi yang dibuat oleh setiap unit dari $\mathrm{CE}$ terhadap value added organisasi.

VACA = VA/CE

Keterangan:

VACA = Value Added Capital Employed: rasio dari VA terhadap CE.

$\mathrm{VA}=$ value added

$\mathrm{CE}=$ Capital Employed: dana yang tersedia (ekuitas, laba bersih)

3. Menghitung Value Added Human capital (VAHU)

VAHU menunjukkan berapa banyak VA dapat dihasilkan dengan dana yang dikeluarkan untuk tenaga kerja. Rasio ini menunjukkan kontribusi yang dibuat oleh setiap rupiah yang diinvestasikan dalam HC terhadap value added organisasi.

VAHU $=$ VA/HC

Keterangan :

VAHU = Value Added Human capital : rasio dari VA terhadap HC.

$\mathrm{VA}=$ value added

$\mathrm{HC}=$ Human capital : beban karyawan. 


\section{Menghitung Structural capital Value Added (STVA)}

Rasio ini mengukur jumlah SC yang dibutuhkan untuk menghasilkan 1 rupiah dari VA dan merupakan indikasi bagaimana keberhasilan SC dalam penciptaan nilai.

STVA $=$ SC/VA

Keterangan :

STVA = Structural capital Value Added: rasio dari SC terhadap VA.

$\mathrm{SC}=$ Structural capital : VA $-\mathbf{H C}$

$\mathrm{VA}=$ value added

5. Menghitung Value Added Intellectual Coefficient (VAIC).

VAIC mengindikasikan kemampuan intelektual organisasi yang dapat juga dianggap sebagai indikator kinerja perusahaan (Business Performance Indicator). VAIC merupakan penjumlahan dari 3 komponen sebelumnya, yaitu: VACA, VAHU, dan STVA.

VAIC = VACA + VAHU + STVA

\subsection{Teknik Analisis Data dan Pengujian Hipotesis}

Pengujian asumsi klasik akan dilakukan agar persamaan model regresi yang dihasilkan tidak bias, memiliki varias minimum dan memiliki sifat best liniear unbiased estimator (Gujarati, 2003 dalam Soetedjo dan Mursida 2014). Pengujian asumsi klasik yang digunakan adalah uji normalitas, uji multikolinearitas, uji heteroskedastisitas dan uji autokorelasi.

Metode analisis yang akan digunakan dalam penelitian ini adalah model regresi linier berganda. Analisis regresi digunakan untuk menguji pengaruh variabel independen terhadap variabel independen (Widarjono, 2007 dalam Soetedjo dan Mursida, 2014). Formula analisis regresi sesuai dengan penelitian ini adalah:

$\begin{array}{ll}\text { Y = a }+\mathrm{b} 1 \mathrm{X} 1 & +\mathrm{b} 2 \mathrm{X} 2+\mathrm{b} 3 \mathrm{X} 3+\mathrm{e} \\ \text { Dimana : } & \\ \mathrm{Y} 1 & \text { : Kinerja Perusahaan } \\ \mathrm{X} 1 & \text { : Human capital } \\ \mathrm{X} 2 & \text { : Structural capital } \\ \mathrm{X} 3 & \text { : Costumer Capital } \\ \mathrm{a} & \text { : Konstanta } \\ \mathrm{b} 1, \mathrm{~b} 2, \mathrm{~b} 3 & \text { : Koefisien Regresi } \\ \mathrm{e} & \text { : Error }\end{array}$


Uji signifikansi simultan (uji F) akan dilakukan untuk melihat signifikansi pengaruh variabel independen terhadap variabel dependen secara bersama-sama (Ghozali, 2006). Tahapan yang dilakukan dalam pengujian hipotesis dengan uji $\mathrm{F}$ adalah:

1. Merumuskan hipotesis statistik

$\mathrm{H} 0: \mathrm{b} 1=\mathrm{b} 2=\mathrm{b} 3=0$

Artinya, variabel-variabel independen secara bersama-sama tidak berpengaruh signifikan terhadap variabel dependen.

$\mathrm{H} 1: \mathrm{b} 1 \neq \mathrm{b} 2 \neq \mathrm{b} 3 \neq 0$

Artinya, variabel-variabel independen secara bersama-sama berpengaruh signifikan terhadap variabel dependen.

2. Menentukan kriteria pengujian

Sig. $\mathrm{F}<\alpha, \mathrm{H} 0$ diterima

Sig.F $>\alpha, H 0$

Uji signifikansi individual (uji t) digunakan untuk menunjukkan pengaruh satu variabel independen menerangkan variabel dependen (Ghozali, 2006). Uji t dilakukan dengan tahapan sebagai berikut:

1. Merumuskan hipotesis statistik

$\mathrm{H} 0: \mathrm{b} 1=\mathrm{b} 2=\mathrm{b} 3=0$

Artinya, variabel-variabel independen secara parsial tidak berpengaruh signifikan terhadap variabel dependen.

$\mathrm{H} 1: \mathrm{b} 1 \neq \mathrm{b} 2 \neq \mathrm{b} 3 \neq 0$

Artinya, variabel-variabel independen secara parsial berpengaruh signifikan terhadap variabel dependen.

2. Menentukan kriteria pengujian

Sig.t $<\alpha, \mathrm{H} 0$ diterima

Sig.t $>\alpha, \mathrm{H} 0$ ditolak

\section{HASIL PENELITIAN DAN PEMBAHASAN}

\subsection{Gambaran Umum Sampel Penelitian}

Objek penelitian ini adalah seluruh perusahaan manufaktur yang listing di Bursa Efek Indonesia. Pengambilan sampel dilakukan dengan menggunakan tehnik purposive sampling. Adapun populasi persahaan manufaktur yang listing di BEI adalah 143 emiten. Namun beberapa dari populasi tersebut akan dikeluarkan dari penelitian karena tidak memenuhi syarat yang telah ditetapkan. Terdapat 47 emiten yang harus dikeluarkan dari jumlah populasi karena mengalami kerugian atau tidak menghasilkan laba. Selain itu 13 emiten lain dikeluarkan dari sampel penelitian karena menyajikan laporan keuangan dalam mata uang dollar. Terdapat 12 
perusahaan yang tidak dapat diakses laporan keuangannya dan selebihnya, 71 perusahaan harus dihapus dari sampel penelitian karena data tertentu yang dibutuhkan tidak dapat ditemukan. Total perusahaan manufaktur yang menjadi sampel penelitian ini adalah 38 emiten. Untuk lebih jelasnya proses pengambilan sampel diuraikan sebagai berikut:

Tabel 5.1

Jumlah Sampel Penelitian

\begin{tabular}{|l|l|}
\hline Pengambilan Sampel & Jumlah \\
\hline Populasi perusahaan manufaktur yang listing di BEI & 143 \\
\hline Tidak memenuhi kelengkapan data yang dibutuhkan & $(71)$ \\
\hline Tidak menghasilkan laba (rugi) & $(47)$ \\
\hline Menyajikan laporan keuangan dalam mata uang dollar & $(13)$ \\
\hline Laporan keuangan tidak dapat diakses & $(12)$ \\
\hline Jumlah sampel penelitian & $\mathbf{3 8}$ \\
\hline
\end{tabular}

Sumber: data diolah 2016

\subsection{Hasil Uji Hipotesis}

a. Uji Koefisien Determinasi ( $R$ square)

Tabel 5.8 Uji Koefisien Determinasi (R square)

Model Summary ${ }^{\mathrm{b}}$

\begin{tabular}{|l|l|l|l|l|l|}
\hline $\begin{array}{l}\text { Mode } \\
1\end{array}$ & $\mathrm{R}$ & $\mathrm{R}$ Square & $\begin{array}{l}\text { Adjusted R } \\
\text { Square }\end{array}$ & $\begin{array}{l}\text { Std. Error of } \\
\text { the Estimate }\end{array}$ & $\begin{array}{l}\text { Durbin- } \\
\text { Watson }\end{array}$ \\
\hline 1 &, $622^{\mathrm{a}}$ &, 387 &, 361 &, 05584 & 1,500 \\
\hline
\end{tabular}

a. Predictors: (Constant), STVA, VACA, VAHU

b. Dependent Variable: ROA

Terlihat nilai $\mathrm{R}$ square menunjukkan angka 0,387. Hal ini mengindikasikan bahwa kontribusi variabel Human capital, Structural capital dan variabel Customer capital terhadap Return on Asset adalah sebesar $38,7 \%$, sedangkan $61,3 \%$ ditentukan oleh faktor lain.

b. Uji F Statistik (Simultan)

Tabel 5.9 Uji F Statistik

ANOVA $^{\mathrm{a}}$

\begin{tabular}{|ll|l|l|l|l|l|}
\hline \multicolumn{2}{|l|}{ Model } & $\begin{array}{l}\text { Sum of } \\
\text { Squares }\end{array}$ & Df & $\begin{array}{l}\text { Mean } \\
\text { Square }\end{array}$ & F & Sig. \\
\hline \multirow{2}{*}{1} & Regression &, 142 & 3 &, 047 & 15,143 &, $000^{\mathrm{b}}$ \\
\hline & Residual &, 225 & 72 &, 003 & & \\
\hline
\end{tabular}

a. Dependent Variable: ROA

b. Predictors: (Constant), STVA, VACA, VAHU 
Dari hasil output data dapat dilihat bahwa nilai uji $\mathrm{F}$ adalah 15,143 dengan nilai signifikansi yaitu $\mathbf{0 . 0 0 0}<\mathbf{0 . 0 5}$. Hal ini menunjukkan bahwa variabel variabel Human capital, Structural capital dan variabel Customer capital secara bersama-sama (simultan) mampu menjelaskan pengaruhnya terhadap variabel Return on Asset, dan signifikan.

\section{c. Uji Parsial}

Berdasarkan output spss regresi linear berganda pada tabel 5.10 maka dapat dirumskan persamaan regresi sebagai berikut:

$\mathrm{VAIC}=0,15-0,007 \mathrm{VAHU}+0,070 \mathrm{STVA}+0,102 \mathrm{VACA}$

Berdasarkan hasil regresi dapat disimpulkan bahwa dengan nilai $\mathrm{F}$ hitung sebesar 15,143 dengan tingkat signifikansi 0,000 (lebih kecil dari $\alpha$ $=0.05$ ), menunjukkan bahwa model regresi antara variabel bebas VAHU, STVA dan VACA serta variabel terikat ROA layak untuk dijadikan model regresi. Untuk mengetahui seberapa besar pengaruh variabel bebas yaitu VAHU, STVA dan VACA terhadap variabel terikat ROA dapat dilihat dari besarnya nilai koefisien regresi sebagai berikut:

1. Nilai koefisien VAHU sebesar - 0,007 memiliki arti, jika VAHU mengalami kenaikan sebesar 1 satuan maka variabel ROA akan mengalami penurunan sebesar 0,007 satuan.

2. Nilai koefisien STVA sebesar 0,070 memiliki arti, jika STVA mengalami kenaikan sebesar 1 satuan maka variabel ROA akan mengalami kenaikan sebesar 0,070 satuan. Sebaliknya, jika STVA mengalami penurunan sebesar 1 satuan, maka ROA juga akan mengalami penurunan sebesar 0,070 satuan.

3. Nilai koefisien VACA sebesar 0,15 memiliki arti, jika VACA mengalami kenaikan sebesar 1 satuan maka variabel ROA akan mengalami kenaikan sebesar 0,15 satuan, dan sebaliknya, jika VACA mengalami penurunan sebesar 1 satuan maka ROA juga akan mengalami penurunan sebesar 0,15 satuan.

4. Nilai constant adalah sebesar 0,929 mempunyai arti bahwa jika variabel bebas yang terdiri dari VAHU, STVA dan VACA konstan, maka diprediksi ROA akan mengalami kenaikan sebesar 0,929 satuan. 
Tabel 5.10 Uji t-hitung

Coefficients $^{\mathrm{a}}$

\begin{tabular}{|ll|l|l|l|l|l|}
\hline \multirow{2}{*}{ Model } & \multicolumn{2}{|l|}{$\begin{array}{l}\text { Unstandardized } \\
\text { Coefficients }\end{array}$} & \multicolumn{2}{l|}{$\begin{array}{l}\text { Standardized } \\
\text { Coefficients }\end{array}$} & $\mathrm{t}$ & \multirow{2}{*}{ Sig. } \\
\cline { 3 - 5 } & & $\mathrm{B}$ & Std. Error & Beta & & \\
\hline \multirow{4}{*}{1} & (Constant) &, 015 &, 016 & &, 929 &, 356 \\
& VACA &, 102 &, 016 &, 654 & 6,421 &, 000 \\
& VAHU &,- 007 &, 002 &,- 492 & $-3,347$ &, 001 \\
& STVA &, 070 &, 027 &, 361 & 2,617 &, 011 \\
\hline
\end{tabular}

a. Dependent Variable: ROA

a. Pengujian Hipotesis 1

Human capital berpengaruh positif signifikan terhadap kinerja perusahaan. Dari tabel t-hitung dapat dilihat bahwa VAHU memiliki nilai t-hitung 2,617 pada sig $0,011>0,05$, dan $\beta(+)=0,361$ artinya pengaruhnya signifikan dan negatif. Hal ini menunjukkan bahwa variabel VAHU (X1) berpengaruh signifikan dan negatif terhadap ROA (Y), dan kesimpulannya hipotesis 2 ditolak.

b. Pengujian Hipotesis 2

Structural capital berpengaruh positif signifikan terhadap kinerja perusahaan. Dari tabel t-hitung dapat dilihat bahwa STVA memiliki nilai t-hitung 6,421 pada sig $0,000>0,05$, dan $\beta(+)=0,654$ artinya pengaruhnya signifikan dan positif. Hal ini menunjukkan bahwa variabel STVA (X2) berpengaruh signifikan dan positif terhadap ROA (Y), dan kesimpulannya hipotesis 3 diterima.

c. Pengujian Hipotesis 3

Customer capital berpengaruh positif signifikan terhadap kinerja perusahaan. Dari tabel t-hitung dapat dilihat bahwa VACA memiliki nilai t-hitung 6,421 pada sig $0,000>0,05$, dan $\beta(+)=0,654$ artinya pengaruhnya signifikan dan positif. Hal ini menunjukkan bahwa variabel VACA (X3) berpengaruh signifikan dan positif terhadap ROA (Y), dan kesimpulannya hipotesis 1 diterima.

\subsection{Pembahasan}

\section{a. Pengaruh intellectual capital (VAIC) terhadap kinerja perusahaan secara simultan}

Secara simultan dengan menggunakan uji $\mathrm{F}$, hasil penelitian ini menunjukkan bahwa intellectual capital yang diukur melalui metode VAIC 
secara bersama-sama memiliki pengaruh yang signifikan terhadap kinerja perusahaan yang diukur melalui ROA. Tampak pada tabel 5.9 nilai signifikansi $0,000<0.05$.

Perusahaan manufaktur yang butuh inovasi produk yang terus menerus digerakkan oleh intellectual capital. Hasil penelitian ini sesuai dengan hasil penelitian terdahulu (Soetedjo dan Mursida, 2014) yang menyatakan secara simultan intellectual capital berpengaruh signifikan terhadap kinerja keuangan. Hasil penelitian yang sama ditemukan oleh Akanbi, 2016 yang merekomendasikan perusahaan memberikan perhatian terhadap intellectual capital karena dapat membawa kinerja yang superior bagi perusahaan dan keunggulan bersaing yang berkelajutan. Menurut Akanbi (2016), pengelolaan intellectual capital yang efisien akan melahirkan motivasi dan dedikasi karyawan, nilai pasar yang lebih tinggi bahkan dapat menjadi pemimpin di pasar.

Hasil penelitian Ahmad (2011) menemukan, terdapat hubungan yang positif antara intellectual capital yang terdiri dari human capital, structural capital, customer capital dan relation capital terhadap kinerja perusahan. Daneshi (2013) menemukan bahwa intellectual capital berpengaruh positif terhadap kinerja perusahaan yang dilihat dari ROA, ROE dan net profit margin. Hasil penelitan lain yang mendukung hal ini adalah Chairunissa dan Dewi (2015), Nejadirani (2012), Yudhanti (2011), Ulum et, al,. (2008).

\section{b. Pengaruh intellectual capital (VACA, VAHU, STVA) terhadap kinerja perusahaan secara parsial}

Secara parsial dengan menggunakan uji t, hasil penelitian ini menunjukkan bahwa kompenen pembentuk intellectual capital yaitu customer capital dan dan structural capital berpengaruh signifikan positif terhadap kinerja perusahaan namun human capital mengunjukkan pengaruh yang negatif signifikan.

Hipotesis pertama yang berbunyi, human capital berpengaruh positif dan signifikan terhadap kinerja perusahaan tidak dapat diterima. Hasil penelitian ini menemukan bahwa human capital (VAHU) berpegaruh negatif signifikan terhadap kinerja perusahaan. Hasil penelitian ini bertentangan dengan hasil penelitian terdahulu yang dilakukan oleh Ahmad (2011) dan Juma (2006) yang menyatakan bahwa human capital berpengaruh langsung dengan kinerja perusahaan.

Perbedaan hasil penelitan tersebut dapat dijelaskan oleh fenomena berikut. Hasil penelitian yang berpengaruh negatif menunjukkan bahwa 
perusahaan manufaktur di Indonesia belum cukup menyalurkan dana untuk pengelolaan modal manusia yang dimiliki yaitu karyawan. Artinya dana yang dikeluarkan untuk kesejahteraan dan pelatihan karyawan masih kurang signifikan untuk mendapatkan karyawan yang sesuai dengan kebutuhan perusahaan.

Beberapa penelitian juga menemukan hasil yang sama dengan penelitian ini. Kuryanto dan Syafruddin (2008) menemukan bahwa pengaruh Intellectual capital (human capital) terhadap kinerja perusahaan manufaktur tidak signifikan. Hal ini disebabkan perusahaan manufaktur masih menggunakan banyak asset tetap dalam proses operasionalnya. Demikian halnya hasil penelitian yang dilakukan oleh Gany dan Nugrahanty (2015) menemukan hasil yang sama. Indikator VAHU tidak valid untuk mengukur variabel Intellectual Capital. Hal ini menunjukkan bahwa perusahaan manufaktur lebih menekankan pada pengolahan physical asset (capital employed) dalam human capital.

Hipotesis kedua yang berbunyi, structural capital berpengaruh positif dan signifikan terhadap kinerja perusahaan diterima. Nilai structural capital (STVA) yang positif dan signifikan menunjukkan bahwa perusahaan mampu memanfaatkan struktur perusahaan yang mereka miliki secara optimal untuk menciptakan laba bagi perusahaan. Dengan adanya struktur perusahaan yang baik, sistem, prosedur, regulasi dan data base yang baik, perusahaan mampu meminimalisasi kemungkinan adanya kecurangan dengan demikian seluruh staff bekerja dengan maksimal.

Hasil penelitian ini sesuai dengan hasil penelitian terdahulu oleh Soetedja dan Mursida, 2014 yang menyatakan bahwa Value Added Structural capital memiliki pengaruh signifikan positif terhadap kinerja perusahaan. Hasil penelitian Gozali dan Hatane (2014) menemukan bahwa diantara ke tiga komponen intellectual capital, pengaruh structural capital terhadap kinerja perusahaan adalah yang paling tinggi. Hasil penelitian lain yang mendukung hubungan positif structural capital dengan kinerja perusahaan ditemukan oleh Haniyah dan Priyadi (2014), Akanbi (2006), Divianto (2010).

Hipotesis ketiga yang berbunyi customer capital berpengaruh positif dan signifikan terhadap kinerja perusahaan diterima. Nilai customer capital (VACA) menunjukkan nilai yang signifikan dan positif terhadap kinerja perusahaan manufaktur. Hal ini menunjukkan bahwa terdapat hubungan baik antara perusahaan dengan konsumen. Usaha perusahaan memberikan pelayanan kepada konsumen, serta merespon saran dan kritik yang disampaikan oleh konsumen mampu meningkatkan kepercayaan 
konsumen kepada perusahaan. Kepercayaan tersebut akan menjadikan konsumen loyal dan tetap memilih produk perusahaan tersebut.

Nilai yang signifikan dan positif tersebut berarti perusahaan menjaga baik hubungannya dengan kosumen). Customer capital yang positif dan signifikan didefenisikan sebagai asset tidak berwujud yang dapat membantu perusahaan dalam hal mendapatkan keunggulan bersaing (Alder dan Kwon, 2002 dalam Juma, 2006). Hasil penelitian ini sejalan dengan hasil penelitan sebelumnya yaitu Soetedja dan Mursida, 2014. Hasil penelitian lain yang mendukung hubungan positif customer capital dengan kinerja perusahaan ditemukan oleh Akanbi (2006) dan Juma (2006).

\section{KESIMPULAN DAN SARAN \\ 6.1 Kesimpulan}

Penelitian ini bertujuan untuk menguji pengaruh intellectual capital yang terdiri dari human capital, structurald capital dan customer capital terhadap kinerja perusahaan yang diukur dengan ROA. Berdasarkan hasil penelitan yang dilakukan terhadap ke tiga hipotesis yang menggunakan analisis regesi linier berganda makan diperoleh kesimpulan sebagai berikut:

a. Human capital berpengaruh tidak signifikan dan negatif terhadap kinerja perusahaan.

b. Structural capital berpengaruh signifikan dan positif terhadap kinerja perusahaan.

c. Customer capital berpengaruh signifikan dan positif terhadap kinerja perusahaan.

\subsection{Saran}

a. Dalam penelitian ini harus mengeluarkan banyak sampel perusahaan dari populasi karena banyak data yang tidak dipenuhi sesuai dengan kebutuhan. Penelitian selanjutnya dapat mengupayakan jumlah sampel yang lebih banyak misalnya dengan menambah jangka (tahun) penelitian.

b. Untuk penelitian selanjutnya dapat menganalisis pengaruh intellectual capital terhadap kinerja perusahaan yang diukur dari base non keuangan yaitu menggunakan quisionaire untuk mengukur intellectual capital. 


\section{DAFTAR PUSTAKA}

Ahmad, Saari bin dan A. M. Mushraf. 2011. The Relationship Between Intellectual Capital and Business Performance: An Empirical Study in Iraq Industry

Akanbi, Paul A. 2016. Exploring the Link Between Intellectual Capital and Perceived Organizational Performance. International Journal of Information, Business and Management, Vol.8, No.2

Alizadeh, Rahmat, S. A. N. Chashmi dan A. J. Bahnamiri. 2014. Corporate Governance and Intellectual Capital. Management Science Letters 4: 181-186

Ballas, A. A., Chalevas, C., dan Tovas. 2012. Market Reaction to Valuation Adjustments for Financial Instruments: Evidence from Greece. Journal of International Accounting, Auditing and Taxation, 21 (1), 52-61

Chairunissa, Citra dan R. R. Dewi. 2015. Pengaruh Intellectual Capital Terhadap Kinerja Keuangan Perusahaan dan Penilaian Pasar dengan Corporate Governance sebagai Variabel Moderasi. Jurnal Akuntansi Trisakti (e-Journal) Vol. 2, No. 2

Chau, G., dan Leung. 2006. The Impact of Board Composition and Family Ownership on Audit Committee Formation: Evidence from Hong Kong. Journal of International Accounting, Auditing and Taxation, 15 (1), $1-15$

Chen, Yu-Shan. 2008. The Positive Effect of Green Intellectual Capital on Competitive Advantages of Firms. Journal of Business Ethics 77: 271-286

Chi, W., dan Wang. 2010. Accounting Conservatism in a Setting of Information Asymetry Between Majority and Minority Shareholders. The International Journal of Accounting, 45 (4), 465-489

Ciptaningsih, Tri. 2013. Uji Pengaruh Modal Intelektual terhadap Kinerja Keuangan BUMN yang Go Public di Indonesia. Jurnal Manajemen Teknologi. Vol. 12 No.3

Daneshi, Ali, I. B. Mansourabad dan A. Pirzad. 2013. The Study of the Relationship Between Intellectual Capital and Financial Performance of the Listed Companies in Tehran Stock Exchange. Research Journal of Applied Science, Engineering and Technology 6 (10), 1703-1710

Divianto. 2010. Pengaruh Faktor-Faktor Intellectual Capital (Human capital, Structural capital dan Customer capital ) Terhadap Business Performance Survey Pada Perusahaan Swasta di Palembang. Jurnal Ilmiah Orasi Bisnis Edisi Ke-IV, ISSN: 2085-137 
Gioacasi, Diana. 2010. Intellectual Capital: A Critical Approach on Definitions and Categorization. CES Working Papers-Volume VI, Issue 4

Gozali, Adrian dan S. E., Hatane. 2014. Pengaruh Intellectual Capital terhadap Kinerja Keuangan dan Nilai Perusahaan Khususnya di Industri Keuangan dan Industri Pertambangan yang Terdaftar di Bursa Efek Indonesia. Universitas Kristen Petra

Haniyah, Faricha N., dan M. P. Priyadi. 2014. Pengaruh Intellectual Capital terhadap Kinerja Perusahaan Otomotif di Bursa Efek Indonesia. Jurnal Ilmu dan Riset Akuntansi Vol. 3 No.5

Hitt, Michael A., R.D. Ireland dan R.E. Hoskisson. 2007. Strategic Management Competitiveness and Globalization: Concepts and Cases. United States of America: Thomson South Western

Hitt, Michael A., L.Bierman dan K. Shimizu. 2000. Direct and Moderating Effects of Human capital on Strategy and Performance in Professional Service Firms: A Resource-Based Perspective

Indriastuti, Maya, D. A. Arifah. 2012. Peningkatan Kinerja UKM dengan Pengelolaan Intellectual Capital dan Inovasi. CBAM-FE UNISSULA Vol.1 No.1

Juma, Norma dan J. McGee. 2006. The Relationship between Intellectual Capital and New Venture Performance: An Emperical Investigation of the Moderating Role of the Environment. International Journal of Innovation and Technology Management Vol.3, No. 4: 379-405

Kusumowati, Minanti. 2013. Pengaruh Intellectual Capital Terhadap Kinerja Perusahaan, Studi Kasus pada Perusahaan Manufaktur yang Terdaftar di Bursa Efek Indonesia. Universitas Diponegoro, Semarang

Nejadirani, Farhad, F. G. Namvar, R. Rasouli dan L. M. Yadegari. 2012. Eximining the Effects of Intellectual Capitals Management on Organizational Performance: The Case Study. Research Journal of Applied Science, Engineering and Technology 4(9): 1040-1050

Ongkorahardjo, Martina D. P. A., A. Susanto dan D. Rachmawati. 2008. Analisis Pengaruh Human capital Terhadap Kinerja Perusahaan (Studi Empiris pada Kantor Akuntan Publik di Indonesia). Jurnal Akuntansi dan Keuangan, Vol.10, No.1: 11-21

Pardede, Fernando. 2010. Relationship Analysis of Financial Performance Intellectual Capital Insurance Company in Indonesia Stock Exchange. Undergraduate Program, Economy Faculty, Gunadarma University 
Sihotang, Parulian dan Y. Sanjaya. 2009. Reporting Intellectual Capital In Annual Reports: Evidence from Indonesia. Indonesian Capital Market Review, Vol.1, No.2: 125-152

Soetedjo dan Mursida. 2014. Pengaruh Intellectual Capital terhadap Kinerja Keuangan pada Perusahaan Perbankan. Seminar Nasional Akuntansi 17 Mataram, Lombok

Sofia, Myrna. 2010. Intellectual Capital pada Sektor Perbankan di Indonesia. JEMI, Vol.1, No.1

Sofian, Saudah, M. Tayles dan R. Pike. 2006. The implications of intellectual capital on performance measurement and corporate performance. Jurnal Kemanusiaan Vol. 08:13-24

Survilaite, Simona, R. Tamosiuniene dan V. Shatrevich. 2015. Intellectual Capital Approach to Modern Management Through the Perspective of a Company's Value Added. Business:Theory and Practice; 16(1):31-44

Ulum, Ihayul, I. Gozali dan A. Chariri. 2008. Intellectual Capital dan Kinerja Keuangan Perusahaan: Suatu Analisis dengan Pendekatan Partial Least Square. Simposium Nasional Akuntansi XI

Westhuizen, C. Van Der dan J. A. Kok. Intellectual Capital Management in South African Retail Company. South African Journal of Information Management Vol. 8(4)

Yudhanti, Ceicilia B. H. dan J. C. Shanti. 2011. Intellectual Capital dan Ukuran Fundamental Kinerja Keuangan Perusahaan. Jurnal Akuntansi dan Keuangan Vol.13 No. 2 